\title{
Common fixed points for almost Presić type operators
}

\author{
MĂDĂLINA PĂCURAR
}

\section{ABSTRACT.}

The existence of coincidence points and common fixed points for almost Presić operators in a metric space setting is proved. A multi-step iterative method for constructing the common fixed points is also provided.

DePARTMENT OF STATISTICS, ForeCAST AND MATHEMATics

"BABEŞ-BOLYAI" UNIVERSITY

T. MiHAli 58-60, 400591 Cluj-NAPOCA, ROMANiA

E-mail address: madalina.pacurareecon.ubbcluj.ro convergence. 